\title{
Russian Legal Discourse
}

\author{
By Vladimir Orlov*
}

Due to the nonrecognition of the origin of the business law in the commercial law, or, the law merchant, grown out of the customs and usages of merchants that existed before the emergence of law itself, and which, even in the process of formalizing the law into the legislation, characteristic for the continental law, in respect of commercial activities that introduced its public regulation, has reserved its self-regulatory and dispositive nature, the Russian legal discourse is quite different to what is generally represented as the Western legal discourse. Although Russian business law has been developed under the influence of Western law, the idea of the legislatively established legal surveillance of business activities, where written law is regarded as a progressive means of regulation, plays still an important role, and the breach of the law requirements is a sine qua non condition for civil liability (for damages) in Russia.

Keywords: Law, Legal Discourse; Legislation; Praxis, Regulation

\section{Introduction}

This article handles issues related to the Russian legal discourse that means Russian law in a very large sense, including the issues ordinary regarded as not being legal. The article contains the parts that are devoted to:

- basic concepts in general, including legal discourse and legal sources,

- genesis of Russian law,

- Russian legal system and

- peculiarities of Russian legal discourse, and ends with conclusion.

The aim of the article is to draw attention to the doctrinal inadequacy of Russian law to the needs of business activities in Russia., ${ }^{2,3}$

The article is based on the notion that our knowledge has a cognitive basis, and it is constructed of our visions on reality - this could be scientist reality, legal

\footnotetext{
"Dr. of Legal Sciences; Professor, Herzen State Pedagogical University of Russia, Saint Petersburg, Russia and Adjunct Professor, University of Helsinki, Helsinki, Finland.

Email: vladimir.orlov@saunalahti.fi

${ }^{2}$ As a consequence of it, it is still generally expected (even among the law students) in Russia, that enforcement authorities act within the law whereas entrepreneurs ought to follow the law. See, for instance, https://deloros.ru/na-ploshhadke-delovoj-rossii-obsudili-zashhitu-biznesa-ot-silovogo-dav leniya-v-pfo.html; https://ria.ru/20210125/zakon-1594499687.html; https://vn.ru/news-yuriy-petuk hov-otvetstvennost-biznesa-eto-garantiya-nadezhnosti

${ }^{3}$ On the modern legal doctrine see, for instance, Orlov (2019) at 164-165.
} 
reality, metaphysical reality, pragmatic reality, etc. ${ }^{4}$ In any case the article represents the realistic approach: as reality, the law exsts, though the difficulties of its definition, for instance, in the legislative and jurisprudential acts, ${ }^{5}$ wherefore phenomenological reality demension is characteristic of law.

Furthermore, according to the nonlinear scientific notions, the world, in particular, the social world consists of mass phenomena, the items of which are self-determining, wherefore exact knowledge on them is impossible ${ }^{6}$. Thus, social (and also legal) phenomena may not in principle be definitely determined, since they always contain an element of unpredictability. ${ }^{7}$

Important is also that legal phenomena are subject of the behavioural sciences, where the intentionality is a decisive factor in defining the content of the issue in question, wherefore we may not deal with the exact knowledge on them but only present our interpretation of the issue. ${ }^{8}$

The development of Russian business law in this article is followed in relation to the influence of Roman law ${ }^{9}$ on it. In this context, the whole body of Roman law and its development could be divided into two stages: the formation of classical Roman law and Justinian and post-Justinian period.

With respect to business regulation, the formation of classical Roman law could be schematically presented as having started in Hellenistic East, where customs established in the Mediterranean Sea trade as being a sort of common lex mercatoria maritima formed Rhodian maritime law code (Lex Rhodia) ${ }^{10}$ that survived until the Roman Empire and was adopted to the Roman law as corresponding the demands of the economically developing society. The Roman law that obtained theoretical and value ground in the Antique Greece became positivistically shaped in classical period law, and in the Justinian period it became codified as Corpus Juris Civilis, containing civil law and canon law norms. Noteworthy is that the interpretation of the Corpus was ordered by Justinian to be based on its texts without any references to the original sources, meaning the opinions of classical roman law scholars ${ }^{11}$; that was the way the exegetical (or literal) principle of interpretation ${ }^{12}$ became applicable in Roman law.

The second part of the history of Roman Law that continued the Justinian

\footnotetext{
${ }^{4}$ To some extent real knowledge (including understanding) could be constructed of positivist knowledge, taking into account the teleological (intentional) aspect of human activity and placed in its cultural values background von Wright (1971) and Egidi (2009).

${ }^{5}$ And its purport is first of all to prevent and solve social collisions.

${ }^{6}$ Even in the exact sciences it is impossible to reach definitely exact knowledge.

${ }^{7}$ See, for instance, Orlov (2019) at 164-165.

${ }^{8}$ It is obvious that such revolutionary notions threaten the established Post soviet scientific order.

9The term "Roman law" firstly refers to the legal system of ancient Rome from the time of the city founding in $753 \mathrm{BC}$ until the fall of the Western Roman Empire in the 5th century CE. Later it was used in the Byzantine Empire (Eastern Roman Empire) until 1453. "Roman law" is also used to denote the legal systems implemented in the Western Europe until as late as the 18th century known as ius commune. See, for instance, Lucio (2021),

${ }^{10}$ Probably issued in about $900-800$ BC.

${ }^{11}$ Pokrovsky (1913), Chapter V.

${ }^{12}$ According to the Exegetical teachings law and statute are identical, and the other sources of law - custom, scholarship, case law, natural law — had only secondary importance. See, for instance, van Caenegem (1992) at 191.
} 
code is represented by its eastern and western branches, and they were essentially different. The western tradition of Roman law $^{13}$ became later realised in the continental law, where civil law became crowned by the codified legislation with its sophisticated theoretical basis corresponding the needs of economic and societal development. ${ }^{14}$ In turn the eastern branch of Roman law ${ }^{15}$, after continuing successfully the Justinian heritage for centuries, lost as such its novelty and universality later. $^{16}$

\section{Basic Concepts in General}

Legal discourse stands in this article for issues related to the law. Freedom of business activities, including free contracting, is the basic principle of the western legal discourse, that had been inherited from the trade customs. These customs were the embryos of the lex mercatoria that forms the basis of commercial law. Even in the process of formalizing the law into the legislation, which is characteristic for the continental law, the law regulating business (commercial) activities, although it introduced the public regulation of these activities, has reserved its self-regulatory and dispositive nature, as well as effectiveness, particularly due to the positive attitude to business customs.

The core of legal discourse is represented by laws or legislative norms in continental law and binding decisions on previous cases at common law. They both serve as constructive elements of the national legal systems that usually include also customs legal doctrine. They all constitute the legal sources, the concept and doctrine of which became necessary due to the systematisation of the modernised western law that took form of codifications in continental law countries started in the beginning of the $19^{\text {th }}$ century and had replaced the traditional particularity of legal regulation.

It was the developing market economy and political democratisation, that presupposed clearly functioning legal orders where predictability and equality were important values, which made a normative theory of how different sources of law should relate to one another necessary. Consequently, the continental legal formalism based on the new concept of sources of law made written norms the most important source of law and (national) legal codifications necessary. Similar predictability of legal regulation is secured by the theory of stare decisis at

\footnotetext{
${ }^{13}$ Significant step in the history of Roman law was the recovery of the Corpus Juris Civilis and, in particular, its Digest or Pandect of Civil Law that contained the extracts from the authoritative writings of the leading Roman lawyers in $11^{\text {th }}$ century in Italy. It initiated academic studies and teaching of Roman law in Western Europe.

${ }^{14}$ The limits of its theorization the Roman law achieved in the German conceptual jurisprudence that represents a conceptually closed system of civil law.

${ }^{15}$ Where the Corpus Juris Civilis was revised into Greek, when that became the predominant language of the Eastern Roman Empire.

${ }^{16}$ Compared to Byzantine, the shaping of the modern western state occurred in different situation that favoured intensive state and societal construction where new social relations and institutes emerged together with the new law. Hvostova (1998) at 2.
} 
common law. ${ }^{17}$

The systematisation of Western law was supported by theorisation of law mainly represented by competing positivist and natural law theories. The concept of legal source has been particularly necessary for the theorisation of positive law in order to avoid further appeal to the doctrinal scholastic or metaphysics, explaining the origin of law in the nature or the existential thinking.

In the modern doctrine continental laws and common law precedents as legal sources are equated, but at the same the issues related to legislation and the issues related to judicial decisions are differentiated into issues of legisprudence and jurisprudence. It is also regarded important, for instance, in the Finnish legal doctrine that the legal science as well as the history, sociology and philosophy of law are distinguished in the legal discourse in particular from the jurisprudence because of the different scientific nature of this - the legal discourse deals with the competences oriented to the judicial activities. In turn, the legal science is nowadays aimed mainly at securing the legal system and its coherence.

Legal sources comprehend normativistically only those legally enlisted, whereas in the descriptive aspect, they mean any factor that has influenced the legal decision, including those that are recognizable only as belonging to the legal discourse in the other legal system. Normativistically, the main legal source is in the continental law the (written) law or statute, whereas at the common law it is the precedent. As the descriptively existing legal sources, cultural factors and real arguments ${ }^{18}$ may be mentioned.

\section{Genesis of Russian Law}

Russian law ${ }^{19}$ and, correspondingly, its legal discourse has specific features that are explained by the historical factors that are related, in particular, to the genesis of Russian law. The historical background of Russian law was formed by old customs, reflecting the agrarian roots of the Russian culture, Byzantine canon ${ } \mathrm{aw}^{20}$ heritage, and influences of' western law. In particular, the influences of' western law, related to the urban development of the country, have been generally respected as an ideal to be striven for, and for stating the successful achievements of them, also rhetoric means are often used. ${ }^{21}$

\footnotetext{
${ }^{17}$ See Pihlajamäki (2020) at 1145.

${ }^{18}$ Real arguments mean, for instance, the arguments that are used or may be used in the pragmatic endeavour of attempting to establish good reasons for beliefs and actions

${ }^{19}$ Russian law, particularly civil law, where the primary legal source is written law or statutory law, shares the continental law tradition. Continental law is characterised as a normative legal system concerning the a priori fixed social behavioural rules that are applicable to concrete cases of social collision through the dogmatic, originally exegetic, interpretation. See, for instance, Orlov (2019) at 118.

${ }^{20}$ Canon Law generally stands for regulation of the issues related to the religion. Specific for the Byzantine canon law was that it was the result of a process of convergence of sources of both ecclesiastical and civil origins.

${ }^{21}$ Usually, and particularly concerning Russia, it is that, in a hope for the wished future, nominations and metaphors are often used to substitute for reality, and, in default of real content, a nomination or a metaphor is supported by its ideological projections.
} 


\section{Joining Byzantine and Roman Law}

The adoption of Christianity by Grand Prince Vladimir of Kiev in 988 opened Russia to a wealth of canon law from Byzantium - the orthodox Christianity has become an essential part of the Russian cultural identity. ${ }^{22}$ That time Byzantium was, after the ruling of Justinian, still at the peak of its historical development. The Byzantine Empire was one of the most powerful military and culturally developed states, and its administration system was highly authoritative, centralised and bureaucratic. Moreover, the Byzantine Empire was a theocracy, where church and state were combined into one all-powerful body ${ }^{23}$ in accordance with the idea of a (Byzantine) symphony ${ }^{24}$ of Church and State. ${ }^{25,26}$ The joining of Russia to the Byzantine church $^{27}$ and law was not, however, legislatively fixed. The canonical and legal realities as well as the cultural and socio-political realities of Byzantium and Rus were significantly different, wherefore the use of the imperial laws and canons in the territories of newly enlightened barbarians ${ }^{28}$ did not seem possible. Consequently, Byzantine canonical rules could be applied in Rus only in so far as they were recognised by church and princes of a certain church and political centre. $^{29}$

The joining of Russia the Byzantine culture and in particular church occurred in church Slavonic language by using Cyrillic letters ${ }^{30}$ after the Bible was translated into a Slav language. This means the creation of not only a script for the Slavs, but

\footnotetext{
${ }^{22}$ After the Mongols destroyed Kiev in 1240, the only source of identity that remained was the religious and cultural alliance with Constantinople. See, for instance, https://www.learnrussianineu. com/religion-russia-history-russian-orthodox-church

${ }^{23}$ The emperor was believed to be both the head of the government and the living representative of Jesus Christ. See https://studyres.com/doc/12152392/the-byzantine-empire

${ }^{24}$ The nomination of different kinds of social relations with the names belonging to the domain of theology and political orthodoxy was usual in Byzantine civilisation. See, for instance, Hvostova (1998) at 21 and 35.

${ }^{25}$ Symphony as a legal concept was formulated by Byzantine emperor Justinian, in his Novella 6 of 535 C.E., and it is readily utilised by the post-Soviet Russian Orthodox Church as the model of ideal church-state relations even at present See Antonov (2020) at 552-570.

${ }^{26}$ Thus, the Byzantine state was a regime in which the sovereign was the head of the church and the state and that he exercised absolute authority and jurisdiction over the ecclesiastical realm. See Pennington (2010) at 183-185.

${ }^{27}$ The choice of religion was most likely determined by political reasons. First, the Slavs had longterm relations with the Byzantine Empire. Second, in the $10^{\text {th }}$ century the Byzantine Empire was one of the most powerful military and culturally developed states. The integration with it on the religious basis was extremely beneficial for the young state. Furthermore, promoting economic, cultural, religious closeness with the Byzantine Empire and other orthodox states, Russian Church was against the Roman Catholic faith, assisting the isolation from the countries of Western Europe and cultural processes, which took place there. See, for instance, https://russia.rin.ru/guides_e/6483.html ${ }^{28}$ This is how Rus was regarded in the Empire of Romans. More details on Greek-Byzantine concept of barbarism and on the attitude of Byzantians to Rus. See Ivanov (2003) at 19-21, 169-172 and 209-223.

${ }^{29}$ See, for instance, Smith (1996) at 2.

${ }^{30}$ In Russia, the Cyrillic script was reformed in the time of Peter the Great whose was to promote the approach of Russia to Europe. The last substantial changes to the Cyrillic script were made after the Great October Revolution. Since 1918 the Russian Cyrillic script has remained the same. See https://www.alanier.at/Orthodoxy.html.
} 
also of a language that became the liturgical language of the whole Eastern church, the Old Church Slavonic. ${ }^{31}$ As modified to the national languages, it continues to be the language of the orthodox Slav churches. ${ }^{32}$ Contrary to the Latin, in particular, scientific Latin, that is the language of philosophical analysis, the Church Slavonic, that appeared during the 14th century and is still used in the Russian Orthodox church, is a sacred language to be used for liturgical worship and hymns. ${ }^{33}$ Consequently, the law adopted in Eastern Europe was incapable of any practical synthesis between the written Roman law of Byzantium and local folk laws ${ }^{34}$. It is also significant that Orthodox Christianity was adopted in Russia at the time when the period of its dogmatic pursuits in Byzantine had ended. Therefore, the Russian religious consciousness has understood the Christian doctrine as being complete and not subject to analysis. Thus, openness to the problematisation of fundamental religious questions had not rooted in Russia. Non-critical attitude to the a priori knowledge has also been (and still is) characteristic for the Russian traditional societal, particularly social scientific, thought that has been oriented towards the exploration and elaboration of the (in the first instance universal) truth composing the system of linearly accumulated knowledge. ${ }^{35}$

For the first five centuries Russian Church was subordinate to Patriarch of Constantinople who appointed its head from among the Greeks. The situation changed in 1051 when the first non-Greek Metropolitan of Kievan Rus' was appointed by Grand Duke Yaroslav the Wise. Russian Church became independent de facto since December 15, 1448, when Moscow did not support the union of the Roman and Byzantine churches and appointed its own head of Russian Church. Then later at the end of the $16^{\text {th }}$ century, Russian Church was recognised independent de jure, and its Metropolitan received the status of Patriarch, formally and officially equal in rights to Greek Patriarchs. ${ }^{36}$ After the fall of Constantinople in 1453, Russian Church declared itself as "Moscow the Third Rome", the sole heir to the true teachings of Christ. ${ }^{37}$

\footnotetext{
${ }^{31}$ For a very short time (868-886) the Old Church Slavonic was acknowledged by Rome as a liturgical language, but it was prohibited $1 \mathrm{n} 886$ by the pope that is considered an important step towards the Great Schism between Eastern and Western church, between Byzantium and Rome.

${ }^{32}$ In medieval Russia the Church Slavonic was the language of the scholars, as Latin in the Western church, and for a very short time (868-886) it was acknowledged by Rome as a liturgical language.

${ }^{33}$ See, for instance, Chulev (2015).

${ }^{34}$ See Giaro (2015) at 314-315.

${ }^{35}$ For more on this subject see, for instance, Zenkovsky (1989) at 3; Mamzin (2008) at 136; Kourany (1998) at 254-257 and Chestnov (2004) at 16-19.

${ }^{36}$ In 1721 the Moscow patriarchate was abolished by Peter the Great, and the Russian Orthodox Church was subordinated to the state through the Holy Governing Synod, a ministry of ecclesiastical affairs under the direction of a lay chief procurator; then the Holy Synod was abolished in 1918 along with all the other governing institutions of the imperial regime. Patriarchy was restored to Russia in 1943. ${ }^{37}$ In general, not all Byzantine doctrines and ideas have been unconditionally accepted in Russia. Especially after the signing of the Union of Florence in 1439 with the Pope and the fall of Constantinople in 1453 in Moscow strengthened the opinion that the Greeks (Byzantines) were punished by God for deviation from the faith, and only in Russia preserved the true faith. It emerged the doctrine of the Third Rome, according to which the historical successor to the Roman and Byzantine empire is Russia. See https://www.geopolitica.ru/en/1068-the-state-and-the-church-inrussia.html. Today Russian Orthodox Church has a rather big influence with the society, and it
} 
Thus, the Russian legal tradition is primarily based on the influences from the Byzantine Empire with its law that was essentially a continuation of Roman law with increased Christian influence. Actually, Russian civil law, including its business regulation provisions, is like the whole body of the Russian law doctrinally based in the Byzantine canon law. ${ }^{38}$ As to the western influences, it was only with the emergence of the Russian Empire in the early 18th century and the Westward-looking leadership of Peter the Great that European influences began to reshape traditional Russian law.

\section{Legal and Societal Development of Russia ${ }^{39}$}

Customary laws were for the first time attempted to be codified in the Russkaya Pravda or Russian justice approximately 1016 in Novgorod. Russkaya Pravda is regarded as the earliest surviving compilation of Russian laws, and contained norms of criminal, obligation, heritage, family and procedure law. ${ }^{40}$ Among the provisions of the Russkaya Pravda were revenge for murder and monetary payment for damages. The first written legislative acts in Russia concentrated on criminal rather that civil matters and focused on regulating the interaction between families. As in the West, Russian society in the 11th century was evolving into a feudal state, in which feudal relations were, however, only weakly defined by customary law. ${ }^{41}$ It was characterised as "feudalism without feudal law." In later versions of the Russkaya Pravda, Byzantine influences were evident, such as the provisions that masters should be liable for crimes committed by their slaves. Also, the Sobornoe Ulozhenie or Cathedral Code of 1649, which was the first attempt at systematic legislation in Russia, shows the influences of the Byzantine (Roman) law; the Ulozhenie survived into the 19th century, when it was replaced by the Svod Zakonov or Body of Laws of $1832 .^{42}$

Although the Byzantine Canon Law norms ${ }^{43}$ were at first purported to handle questions related to the Orthodox religion, they were, however, the result of a process of convergence of sources of both ecclesiastical and civil origins, where civil law norms could not contradict the canons. Since late $6^{\text {th }}$ century canon law collections named nomokanons, issued in Byzantine, combined directly ecclesiastical

sometimes plays an important role in the country's political life. See https://www.learnrussianineu. com/religion-russia-history-russian-orthodox-church

${ }^{38}$ However, even the extremely strong influence of the Orthodox culture of Byzantium was unable to compensate in Russia for the absence of Roman civil law that everywhere in Continental Europe promoted individualism and civil society development. See Avenarius (2014) at 89 and 91.

${ }^{39}$ For more on the history of Russia see, for instance, Munchaev \& Ustinov (2009).

${ }^{40}$ The first Russian legislative acts served the judicial purposes.

${ }^{41}$ Feudalism in Western Europe became between 1050 and 1150 rationalised through the drafting of feudal and manorial laws. Russia, however, remained remote and isolated from these developments.

${ }^{42}$ See, for instance, Smith (1996) at 2 , and Avenarius (2014) at 140-147.

${ }^{43}$ The Byzantine Canon Law norms may be formally hierarchised as follows: (1.) written law, (2.) custom (3.) judicial precedent, Canon Law stands for regulation of the issues related to the religion. Legal norms of the Byzantine Canon Law may be formally hierarchised as follows: (1.) written law, (2.) custom (3.) judicial precedent, (4.) analogy with the law in force, (5.) authorised opinion. However, the highest criterion for the priority of the legal source is the original source of the Canon law that is the will of God. See Kaufhold (2012) at 215-342; and Tsypin (1994). 
(canons) and secular norms or imperial laws. One of the most important Byzantine nomokanons, the Nomokanon of 14 Titles $^{44}$ was translated into Slavic languages and passed into the Russian Church; in the $12^{\text {th }}$ Century it was revised provided with a prologue and commentary by Theodore Balsamon, who was the most important canonist in Constantinople that time. ${ }^{45,46}$

Russian version of the Nomokanon, so-called Kormchaya Kniga ${ }^{47}$ included the rules applicable not only in religious issues but also in judicial and administrative activities concerning secular issues. It was officially recognised by the (Russian) Synod and included in the Svod Zakonov. Then in 1839, it was partly replaced by the new (current) canon law book, the Book of Rules (Книга Правил), where the outdated and irrelevant content was deleted. ${ }^{48}$

The role of Greek clerics, who were well educated, in promoting legal and societal development in Russia was very important. Under the circumstances of the underdeveloped state institutions the clerics were expected to act on the behalf of the state. Following the Byzantine tradition, the church supported the state in securing public order and even morality, particularly in family relations. ${ }^{49}$

In particular, the orthodox clergy was an important factor in the development of old Russian jurisprudence since they possessed the legal material representing the achievements of the Byzantine law based on the best works of the Roman legal scholars. The legal material brought by clerics concerned not so much legislation but rather legal science, and in particular, skills in elaboration, classification and systematisation of legal material, those are the skills they achieved in the studies of sacred texts by applying logical methods. Actually, the Kormchaya kniga, was an example of the fluent presentation of the legal rules that were constructed not on the outdated customs or the occasional decision of the authorities, but on the successfully developed and recognised legal principles corresponding the actual needs of the society. ${ }^{50,51}$

Thus, the Russian (Nomokanon) Kormchaya Kniga followed by the Book of Rules (Книга Правил), the purport of which was to serve as a manual in the church governance and in the ecclesiastical court, created, thanks to their high theoretical

\footnotetext{
${ }^{44}$ The conciliar canons in the first part of it are basic texts of Greek Orthodox ecclesiastical law up to the present time.

${ }^{45}$ In his Scholia (explanatory notes) the text is paraphrased, difficult concepts are interpreted, reference to the reasons which led to the enactment of the canons is made, the text is compared with similar canons, the conflicts with contrary or different texts are pointed out, and harmonisation of the contradictions is attempted. Balsamon's exegetical method is generally similar to that adopted by contemporary canonists of the Latin West.

${ }^{46}$ For more on the subject see, for instance, Hartmann \& Pennington (2012) at 115-169.

${ }^{47}$ For more on the subject see, for instance, https://omolitvah.ru/eto-interesno/chto-takoe-kormcha ya-kniga.

${ }^{48}$ For more on the subject see, for instance, Muravyev (2003) at 318-325.

${ }^{49}$ Russian orthodox church has never pretended to be politically and legally autonomous and fully shared the symphony with the secular power though their competencies were distinguished. See Fogelson (2015) at 41; and for more on the issue see Dorskaya (2016) at 1.

${ }^{50}$ Such a brief-law-book style that followed the synoptic Byzantine codifications became popular in Russia. It strengthened the development of Russian law towards its abstractness.

${ }^{51}$ For more on the subject see, for instance, Muravyev A. (2003) at 318-325, Klyuchevsky (2000) at 328-330 and Tomsinov (2009) at 14-15.
} 
and technical level, the ground for adoption of constructions of the French exegetical jurisprudence and then also German conceptual jurisprudence (Pandect law) in Russian civil law. Moreover, the basis of Russian canon law, without being bound to any legal, in particular civil law tradition, became a platform for value orientation of Russia and its law, originated in the Orthodox Christianity ${ }^{52}$, where law in the meaning Pravda (positive law codification) is also identified with right and justice implying equity and even truth (veritas). So, the Byzantine canon law tradition is the original philosophic root of the Russian law aimed at integrating positive law with moral values and seeking for the verity, often even at the expense of economic rationality.

Since the Byzantine as well as the Russian church was tightly interwoven with the state, religious and secular issues were not properly distinguished, and the canon law norms as a whole were contained in the general system of state laws ${ }^{53}$ with the reservation that such laws are under the competence of the emperor as a universal and absolute lawmaker, who was the head of both the church and the state. ${ }^{54}$ So following the Byzantine tradition ${ }^{55}$, czarist Russia was an ideocratic state and the will of the monarch was the only legal source of law; life in the country was regulated by a great number of normative acts and regulations, but there were no exact laws. ${ }^{56}$

The Russian society was in the first place a hierarchical class society. The state subdued all social classes and institutions, including the church; furthermore, the body of civil servants (but in principle all social groups were under the duties) was a class dependent of the Czar and separate from society. ${ }^{57}$ For upholding societal integrity, the ideological pillars were purported. In addition to orthodoxy, they include sobornost and derzhavnost. Sobornost or conciliarity stands for a form of sociality — or conciliary unity - that expresses and embodies the unity and freedom of its members. ${ }^{58,59}$ In turn, derzhavnost or statehood or primacy of the state means the domination of vertical societal relations, in which the interests of individuals are subordinated to the higher-level interests, usually personified in the

\footnotetext{
${ }^{52}$ Unfortunately, the facts of any practically positive impact of the Russian canon law on ordinary secular life I have not traced. Moreover, it is of common knowledge in Russia that positive (written) law as a means of state governance was unknown in Czarist Russia; fiscal interests of the crown were the main concern of the Russian legislator. In fact, and peasants as individuals were not legal subjects, and mainly they enjoyed living according to the custom law. Furthermore, the utilitarian attitude of the state to the citizens and vice versa is a traditional problem of the Russian society, and to live in accordance with the law is still a challenge in Russia. See Fogelson (2015) at 41-50.

${ }^{53}$ Only between $11^{\text {th }}$ and $12^{\text {th }}$ the law became an autonomous discipline with its own method in the Byzantine East as well as in the Latin West.

${ }^{54}$ The ideal for law in Byzantine was linked to the conception of the Czar's autocratic power, because the emperor was the embodied law, the nomos. Consequently, if you give something a name, you empower it, and when you call something a law it becomes very solemn and strictly adhered to. See https://pravoslavie.ru/49277.html

${ }^{55}$ Contrary to the Roman churches, the orthodox churches are national churches, the priests and patriarchs always considered themselves the first patriots of the country and their most important aim was to serve their nation.

${ }^{56}$ See Orlov (1999) at 359-360.

${ }^{57}$ Even the nobles were set free only on the second half of the $18^{\text {th }}$ century.

${ }^{58}$ The members of such a unity are completely united and completely free at the same time.

${ }^{59}$ See Horujy (2011)
} 
state power, and it also means the habit of appealing not to the law but to the authority of an official. ${ }^{60}$

Strengthening the power of the state and, in particular, its head was the main concern of czar Peter's reforms in the field of law. Also, Catherine II (1762-1796) and Alexander I (1801-1825), in their attempts to modernise the Russian society and law in accordance with the western liberal ideas and models, showed clearly their unwillingness to accept any legal restrictions on their power as sovereign. In general, the use of law and the legal system to reinforce the power of the ruler is characteristic feature of Russian legal culture. The Czar's personal power was at all times superior to any rule, law or statute, and any societal improvement in the country required the enlightened mind of the monarch. Still in the $19^{\text {th }}$ Century, the Russian imperator issued laws and supervised the observance of them. He was also the supreme judge, and he decided on the finance of the state ${ }^{61}$. Administrative regulation has always been dominant in the development of law in Czarist Russia and later. The centralised exercise of power that was adopted from Byzantine law was reflected in the detailed regulation of life and often also as an arbitrary regimentation in Russia. ${ }^{62}$ As to the German concept of Rechtsstaat, or lawruled state, it became known as pravovoe gosudarstvo to Russian constitutional thought only starting from the $1880 \mathrm{~s}^{63}$

Dealing with the consequences of the belated modernization has been the main concern of Russia in respect of developing modern legal system that ought to correspond the needs of economic development. The social and economic development of Russia was really interconnected with the development of modern Russian law. The economic and cultural differences were in Czarist Russia an obstacle to the formation of the uniform family, personal, and property law ideals which were necessary in order that the uniform system of civil law norms could be achieved; however, all attempts at uniform legislation failed, although the gathering of legal norms into bodies of law began in Russia in 1649. Moreover, trade customs were traditionally ignored in Russian law, and commercial activities were not regarded as suitable for the upper classes in the czar Russia. ${ }^{64,65}$ Furthermore, the established feudal society structure ${ }^{66}$ and, in particular serfdom, denied the rights of peasants who were the majority of Russia to exercise commercial activities, and it restrained substantially the development of commodity production in Russia ${ }^{67}$, since the czar Russian agriculture was mainly self-

\footnotetext{
${ }^{60}$ For more on this subject see, for instance, Loskutov \& Tribunskaya (2015) at 345-354.

${ }^{61}$ For more on the subject see, for instance, Bohanov (2002) and Bohanov (2004).

${ }^{62}$ See, for instance, Smith (1996) at 8 and Heuman (1991) at 122-123.

${ }^{63}$ See Giaro (2015) at 316 and the material referred therein.

${ }^{64}$ Nobles are not expected to do any work in Russia, as elsewhere in the traditionally civilised countries and even in the uncivilised world if possible; this concerns in particular men. The same values are particularly shared by the children of the nouveax riches in present Russia.

${ }^{65}$ See, for instance, Puginsky (2013) at 25.

${ }^{66}$ In the legal sense, the Russian society was divided into two flatly different parts: peasants, the life of whom was regulated by custom law, and privileged groups, for which laws were passed; each estate has its own rights and duties.

${ }^{67}$ In the absolutist Russia (the end of the $17^{\text {th }}$ - the first half of the $19^{\text {th }}$ century) the emerging industrial and professional corporations were to survive in the established feudal and absolutist
} 
sufficient. Even according to the Charter of the Cities of 1875 trade activities were a status privilege of merchants. In fact, Russian society was not been much familiar with the market economy tradition. Strong enterprises, independent from the state power were absent in Russia, and business activities were mainly subject to public law regulation that was aimed to secure, in the first instance, public interests. ${ }^{68}$

Particularly in the $19^{\text {th }}$ Century the capitalistic development in Russia met with obstacles which were connected to the dominant social structure, particularly the autocracy and serfdom. Serfdom still restricted the development of markets and entrepreneurship; only a proportion of the estate owners managed, although with difficulty, to adopt to the market economy, but also it fell into crisis after the abolishment of serfdom (1861), because the nobles were unable to use paid work. ${ }^{69}$

Thus, the conditions for organic capitalist market economy development were insufficient. Unrecognition of trade customs and factual nonexistence of free and independent merchants were real obstacles to economic development of Russia. Therefore, the state made efforts to promote business activities by legal means, and the promotion of industry and trade became prioritised in the Government's policy particularly since the $19^{\text {th }}$ century. And in the years between 1861 and 1874, Alexander II decreed his reforms that concerned Russia's social, judicial, educational, financial, administrative, and military systems. The reforms liberated roughly 40 percent of the population from serfdom, created an independent judicial system, introduced self-governing councils in towns and rural areas, eased censorship, transformed military service, strengthened banking, and granted more autonomy to universities. ${ }^{70}$ Furthermore, in the $19^{\text {th }}$ Century, many traditions and institutions of Western European civil law were adopted and law became the main source, while customs were placed second. In particular, the second half of the $19^{\text {th }}$ Century was remarkable: trade law began to be differentiated from civil law and the Statute on Trade reformed in 1887 and 1893 allowed commercial activities by anybody irrespective of the estate, and also commercial customs were applied according to it, but subject to restrictions. The trade legislation contained, however, more organisational than private law norms. ${ }^{71}$

\section{Influences of Roman (Civil) Law}

With the emergence of the Russian Empire in the early 18th century and due to the westernisation policy of Peter the Great, the European influences based on Roman law began to reshape traditional Russian law, and so Roman law began to

system. However, there were peasants who became successful merchants and even equalised with the landlords who served the state as civil servants. See Munchaev \& Ustinov (2009) at 44.

${ }^{68}$ For more on the subject see, for instance, Orlov (1999) at 363 and the material cited therein.

${ }^{69}$ For more on the capitalistic development in Russia see, for instance, Munchaev \& Ustinov (2009) 138-150; as well as Orlov (1999) at 338 and the material cited therein.

${ }^{70}$ Some reforms of Alexander II even succeeded regarding especially the local self-government and judiciary reform. See, for instance, Butler (2009) at 31-32.

${ }^{71}$ But the development of Russian trade law as an independent discipline did not last for long, because the Commission founded in 1884 to prepare the Civil Code of Laws stated that its norms belonged to civil legislation. 
influence Russia law indirectly through the influences of Western European, primarily French and German law. ${ }^{72}$ The actual acquaintance with Roman (civil) law in Russia was related to the necessity of the modernization of Russia and its legal system following the experience of the western Europe in the development of the modern, in particular civil law, based on Roman law. ${ }^{73}$ Following, for instance, the influence of the French exegetical approach to the law, that required strict obedience of the law and ignored doctrinal constructions, the legislative work in Russia reached the significant result. It was the Svod Zakonov or body of laws of the Russian empire published from $1832^{74}$, which contained the civil, state, administrative, criminal, and procedural law normative acts; the private law part of it contained also some Roman transplants. On the whole, the Svod Zakonov was casuistic, unmethodical and unsystematic. In fact, it was more compilation than a codification. $^{75}$

A significant role in the modernization of Russian law, with the reference to Roman law, played the Governing Senate (Pravitelstvuyushchiy Senat) that was a legislative, judicial, and executive body of the Russian Emperors, instituted by Peter the Great, which evolved In the $19^{\text {th }}$ century into the highest judicial body in Russia. For instance, it was the Court of Cassation for civil cases of the Governing Senate who finally acknowledged the distinction between private and public law in the Russian legal practice. ${ }^{76,77}$

In particular, German law attracted much attention in Russia, and German universities were intensively visited by Russian scholars for their studies of Roman law. Still in the end of the $19^{\text {th }}$ century Roman law was in force in Germany, as elsewhere in Western Europe, and the norms of the Corpus Juris Civilis were directly applied in practice. The teaching of pandect law and exegesis of Roman legal texts was very important in Germany due to the particularity of legal regulation (or existence of many legal systems) in the country. Moreover, German law studies were regarded in official Russia as a better alternative to the revolutionary (natural) law ideas emerged by the French revolution. ${ }^{78}$

The next significant step in in the development of Russian civil law was the draft of the Civil Code of Laws, in which the German Pandect doctrine was applied, and this meant the scientific rationalisation of the traditional legal order in Russia. The impact of German private law on the Russian drafts was particularly strong. In the spirit of Pandect Science, Russian institutions were adapted to their

\footnotetext{
${ }^{72}$ Thus, Byzantium was not the conduit of Roman (civil) law to Russia, and in fact, the Corpus Iuris Civilis - neither the original Latin text, nor its Greek version from the late $9^{\text {th }}$ Century, called Basilics - was known in Russia until the end of the seventeenth century.

${ }^{73}$ Before the $19^{\text {th }}$ Century no learned law, no juristic literature and no juristic profession of the western type related to civil law was known to Russia. See Avenarius (2014) at 231-270.

${ }^{74}$ It occurred as a result of the abandoned, due the Napoleonic Invasion of 1812, plans to adopt the French-style civil law in Russia. See Avenarius (2014) at 89 and 91.

${ }^{75}$ Ibid at 202-203.

${ }^{76}$ See, for instance, Avenarius (2014) at 319-321.

${ }^{77}$ Roman law was also subject to the critical attitude in Russia. According to Pobedonostsev, who was a conservative politician and head supervisor for the Russian Orthodox Church, contrary to Roman law with its unlimited egoistic concept of ownership, Russian law was oriented towards the collective consciousness and the hierarchical spirit of the Orthodoxy Ibid at 309.

${ }^{78}$ See Rudokvas (1998).
} 
Roman law patterns. ${ }^{79}$ However, the encoding of Russian civil legislation failed because of the First World War, but the draft of the Civil Code of Laws contributed to the content of the Civil Code of the Soviet period (1922). ${ }^{80}$

The modernisation of the imperial (absolute) Russia and its capitalist future was ended up with the Russian Revolution of 1917. The modernisation efforts of the state had started the contradictory period of the history of Russia.

Still in the beginning of the $20^{\text {th }}$ Century, the Last Russian Czar Nikolai II (1895-1917) continued ideocratic ruling sincerely believing in the divine origin of his power. And he repudiated his power too late, when the country had met the catastrophe connected with the unfortunate participation in World War I and the Revolutions.

\section{Soviet and Modern Russia}

The Revolution was followed by the period of the socialist construction of the society that included also the adoption of the codified civil law modified to the needs of the new society. The first Civil Code of the Soviet period (1922) was an instrument for transition from capitalist to socialist society. However, the adoption of the codified civil law showed a kind of continuity between the pre-revolutionary and the Soviet legal system. Particularly, the continuity concerned in administrative law as well as other branches of public law. ${ }^{81}$

Legal science was purported to play a significant role in the construction of a new socialist society. In accordance with Marxist legal science, the course of history in the new Soviet vision was determined by universal laws (regularities), above all by the means of production and class struggle. ${ }^{82}$ The vision was connected to the belief in man's rationality and ability to construct an ideal society with the revolutionary vision of history. Law, in turn, was understood, in accordance with the principle of revolutionary legalism, as a tool of governance and repression in the interest of the ruling class, meaning in a socialist society legal policy aimed at achieving political goals of the state by legal means. ${ }^{83}$ The application of such a policy led to the emergence of the legal science marked by Marxism, sociological approach and concepts, extreme dogmatism, reference to the authorities as the ultimate argument and self-sufficiency in the Soviet Union. ${ }^{84}$

The Code of 1922 was followed by the Civil Code of 1964 that was a basic civil legislative act of a socialist society. ${ }^{85}$ In accordance with the Code, business

\footnotetext{
${ }^{79}$ See Avenarius (2014) at120-125 and 532.

${ }^{80}$ For more on the development of Russia between the $19^{\text {th }}$ Century and the beginning of the $20^{\text {th }}$ Century see, for instance, Munchaev \& Ustinov (2009) at 138-158 and 198-207; as well as Orlov (1999) at 363-364 and the material cited therein.

${ }^{81}$ Giaro (2015) at 316-317.

${ }^{82}$ Consequently, legal history, including Byzantine law was marginalised as secondary to the economy and class struggle.

${ }^{83}$ In fact, the communist ruling in the Soviet Union was ideocratic. In particular, it concerns the revolutionary times and the Khruschev's period with the caricature believe in the victory of communism as the most scientific theory.

${ }^{84}$ See, for instance, Poldnikov (2019) at 150-155.

${ }^{85}$ For more on this subject see, for instance, Ostroukh (2013) at 373-400.
} 
activities in the Soviet Union were subject to the economic law regulation standing for civil law provisions strengthened by compulsory norms that concerned the formation of contract and its content as well as settlement of disputes.

Industry and trade became priority activities of the state, whereas private business activities became strictly limited and even prohibited in the Soviet Union. A remarkable exception in the Russian business history are the cooperatives that are a modern modification of a traditional Russian artel, association of workers, sometimes mixed with partnership. ${ }^{86}$ In the Soviet Economy, cooperatives in the form of collective farm, or kolhoz played an important role. The same concerned production cooperatives until the "modernization" reforms of Khruschev, strived for the "light communist" future, in the end of 1950s, when the production cooperatives were absorbed to the state sector, and almost any kind of selfinitiative entrepreneurial activity was officially criminalised. However, in 1980s, cooperatives had the renaissance by giving impulse to the expansion of private entrepreneurship in Russia. ${ }^{87}$

The scientifically grounded, directed from the above socialist economic policy succeeded in the building of the fundament of the modern society in the Soviet Union, thanks to the strict and sometimes even extremely strict mobilisation of resources, The mobilisation meant not so much the use of coercive, mainly disciplinary measures, but rather the appeal to general Russian consciousness, and this implicated the ideology and propaganda means that used the metaphysic language comparable with the one used in the Byzantine imperium. But, starting from the late 1960s, the further development of the Soviet economy faced the problems, regardless of the promises of the scientifically proven communist future.

The construction of the socialist future was interrupted by the Perestroika started in the mid-1980s, when Mikhail Gorbachev, the last ruler of the Soviet Union opened the "totalitarian doors" for denial of the socialist past, and due to the massive propaganda for reforms the Perestroika brought the rather massive inspiration to turn to the capitalist alternative. However, "the free-market economy" and "natural capitalist development", scientifically discovered as trustworthy, even as verities in the process of problematization of socialist economy in $1990 \mathrm{~s},{ }^{88}$ brought any particular success, except for the benefits enjoyed by the active part of the Soviet ruling elite through the privatization of the state property.

As a result of the reforms started in the end of the Soviet period, Russia became an independent state with its own legislation including the Constitution and Civil Code, and is politically ${ }^{89}$ and confessionally pluralistic society.

The present Civil Code of 1994-2006 is purported to be the basis for a market

\footnotetext{
${ }^{86}$ Initially, the artel was the traditional association of peasants, usually from the same rural commune, who worked or sought work together away from the village. In the Law of 1902, labour artels were defined as partnerships founded for performance of specific work or production as well as for provision of services through personal work of the participants at their expense and by their collective guarantee.

${ }^{87}$ For more on this subject see, for instance, Orlov (2015) at 413 and the material cited therein.

${ }^{88}$ So, the only one true orthodox faith became replaced by the only one true science.

${ }^{89}$ Major parties in the Russian State Duma are United Russia (Единая Россия; in power), Communist Party (Коммунистическая партия), Liberal Democratic Party (Либерально-Демократическая Партия), and Fair Russia (Справедливая Россия).
} 
economy and a liberal society in Russia, and it has introduced first commercial customs and then customs in general as a legal source to the Russian civil law. ${ }^{90}$ Enterprises are independent and basically act in accordance with the civil law requirements, allowing the application of customs, including trade customs; enterprises are juristic persons and act mainly through the contracts.

\section{Russian Legal System}

As the basis of the Russian legal discourse, the Russian legal system is normativistically defined ${ }^{91}$ and comprehend hierarchically determined legal sources as follows:

The first in the Russian legal system are (written) laws (normative legal acts) divided into

1. Basic laws, including

a) Constitution of the Russian federation (1993) and

b) Constitutions of the subjects of Russian federation, and

2. Federal laws that include Constitutional laws and ordinary laws, and

3. Laws of the subjects of Russian federation.

The Constitution of the Russian federation is the main source of law in Russia. Also, other basic laws of the Russian federation are endowed with the highest legal force. Following the provisions of the Constitution, the federal law takes absolute priority and it may be used to regulate any issue, unless otherwise provided in the Constitution. According to the Civil Code, civil legislation falls under the Constitution within the jurisdiction of the Russian Federation, and it consists of the Civil Code and other federal laws adopted in accordance with it. In respect of all other laws, the Civil Code requires in principle that the norms they include shall be consistent with it. Furthermore, many norms of the Civil Code contain references only to law, and consequently prohibitions to enact or apply a normative act subordinated to the law.

The second in the Russian legal system are (other) normative acts subordinated to the law (substatutory acts), including Ukases (edicts) of the President and Decrees of the Government.

Other normative acts still form a significant part of Russian civil legislation. But, although the legal acts of the President, Government, ministries, and other

\footnotetext{
${ }^{90}$ For more on this subject see, for instance, Ostroukh (2013) at 373-400.

${ }^{91}$ Russian law is also familiar with legal consciousness, natural law, good faith and general principles considerations and academic commentaries and discussions that could be regarded as descriptively existing legal sources. Noteworthy are also the international private law rules. According to the article 1191.1 of the Civil Code, in the application of foreign law, a court establishes the content of its norms in compliance with the official interpretation, application practices and doctrine in the respective foreign state. Thus, the rules of the applicable foreign law are to be regarded as descriptively existing legal sources.
} 
executive authorities of Russia are regarded as civil law sources, they do not belong to the proper civil legislation.

In respect of the ukases of the President, it is provided under the Civil Code that civil law relation may be regulated by them, but only on condition that such ukases are not contradictory with the Civil Code $^{92}$ and other laws.

The legal grounds for the power of the Government to issue decrees containing civil law norms can be, according to the Civil Code ${ }^{93}$, only Civil Code and other laws as well as the ukases of the President, and it restricted only to the implementation of these. The Civil Code and other laws contain sometimes direct provisions on the enactment of decrees of the Government. In certain cases, the Civil Code refers directly to the possibility to issue a law or other legal act, and it also means that the decree of the Government may be applied to the legal relation in question.

In respect of the legal acts of the federal executive bodies or substatutory acts, the Civil Code provides that these bodies may issue acts containing civil law norms, in the cases and within the limits provided by the Civil Code, other laws and legal acts (ukases and decrees) ${ }^{94}$. Thus, the issuance of any administrative normative act must be grounded by the provision of the law or other legal acts.

The priority of the law over the normative acts subordinated to the law is directly enforced in the Civil Code and other laws. In the event of a conflict between an ukase of the President or a decree of the Government and the Civil Code or other law, the provisions of the Civil Code or respective law shall be applied. Thus, the ukases and decrees clearly differ by their legal force from the laws and, consequently, in event the court finds out the contradiction between the ukase or decree and the Civil Code or other law, it is not only its right but also obligation to leave the contradictory normative acts subordinated to the law inapplicable. As to the administrative acts contrary to law, it may be left inapplicable or recognised as invalid by the court.

The third in the Russian legal system are norms of international law and international treaties and the fourth in the Russian legal system are

- other legal sources, including

- customs. $^{95}$

The fifth in the Russian legal system are normative agreements (treaties, contracts) that may, as legal sources, establish the legal rules of behaviour for their participants;

Russian law is acquainted with constitutional and administrative agreements, as well as with labour collective contracts (agreements).

\footnotetext{
${ }^{92}$ Russian Civil Code, art. 3.3.

${ }^{93}$ Russian Civil Code, art. 3.4.

${ }^{94}$ Russian Civil Code, art. 3.

${ }^{95}$ Additionally, Russian law recognises the analogy application. According to the Article 6 of the Civil Code, civil law (legislation) could be applied in a by analogy (the analogy of the legal rule and the analogy of the law), if the law, contract or custom regulating the relation in case is missing. In applying the norm or law by analogy attention should also be paid to the requirements of good faith, reasonableness and justice.
} 
But legal theory (doctrine) has been and is still excluded from legal sources in Russian law; and Judicial practice is also not regarded (at least traditionally) as a proper legal source; however, the precedent decisions of the Constitution Court could be seen as having legislative effect.

Furthermore in 2020 the Supreme Court has obliged the lower courts to check the correspondence of their decisions to its position.

In securing the functioning of the legal system in Russia, the highest judicial bodies, the Constitutional Court and the Supreme Court play an important role, although it is traditionally regarded in the Russian doctrine that judicial institutions do not possess norm-creative functions; they do not create norms of law, but merely interpret and apply them.

The Constitutional Court interprets the Constitution and resolves cases of compliance with the Constitution of federal laws and other normative acts as well as international treaties of Russia that have not entered into force. Furthermore, it resolves disputes about competence between state bodies. The Constitutional Court also considers appeals against a violation of the constitutional rights and inquiries from courts to verify he constitutionality of a law being applied or subject to application in a particular case.

In giving its normative explanations concerning constitutional issues, the Constitutional Court is empowered to deviate from the text-bound interpretation of the legal norms, and has resorted to using this power in the interpretation of, for instance, tax $\operatorname{law}^{96}$. The Constitutional Court has also ventured, in its interpretation of the Constitution, to declare that fairness, legal equality, proportionality, and equity are the principles corresponding to the Constitution, and this may be interpreted as a legislative action.

The Supreme Court of the Russian Federation is the highest judicial body in the resolution of economic disputes and in civil, criminal, administrative and other matters that are within the jurisdiction of lower courts established in accordance with federal constitutional law. It exercises judicial review of the activities of the courts and provides explanations on matters of judicial practice. ${ }^{97}$ There are also separate cassation and appeal courts of general jurisdiction in Russia. Noteworthy is that, although precedent law is not officially recognised in Russia, the role of the highest judicial bodies in securing the adequacy of the Russian legal system is important.

Business activities are, for the most part, regulated in Russia by the Civil Code that is the main civil law source, containing imperative (compulsory) and dispositive legal rules. In respect of contracts, legal sources may be generally hierarchised, in accordance with the Civil Code, as follows:

- The first are imperative norms of the law and

\footnotetext{
${ }^{96}$ For instance, in its decision of 1999 , the Constitutional Court enforced the principle that any ambiguities of tax legislation shall be interpreted in favour of the taxpayer.

${ }^{97}$ The plenums of the Supreme Court in Russia are competent to give not only decisions in concrete appeal cases, but also generalise the judicial practice and pass interpretative rules or guiding explanations on the applicable legal norms obligatory for the lower general courts.
} 
- The second are the terms of the contract agreed upon by the contracting parties.

- The third in contract regulation are dispositive norms which shall be applied in default of the contractual terms, and,

- The fourth are customs (business customs) that are applicable in default of both contractual terms and dispositive norms. ${ }^{98}$

Thus, dispositive norm has priority over business custom in Russia ${ }^{99}$.

\section{Peculiarities of Russian legal discourse}

Specific for Russia is particularly how the law is generally understood. The basic idea of Russian (post-Soviet) law is that it (law, legal reality, legal substance exists as

a) legal consciousness, idea, concept of law (that are the subject of the natural law theory and the psychological theory of law),

b) legal norms (that are the subject of the positivistic and normativistic theories), and

c) social relations (that is subjected to theories of sociology of law).

The sociology of law approach, related to the social engineering, seems however, not to be generally distinguished from the jurisprudence (law in proper sense), and the term of legal order is usually associated with the society effectively governed by the rule of law.

Furthermore, the legisprudence is not properly distinguished from the jurisprudence and legal science. It reflects the scientist approach to the function of law in Russia, which is ordinarily realised in linear thinking, favouring single causal explanations.

In accordance with the general notions of law, Russian (civil) law regulating business activities has, following the traditional continental (in particular, German pandect) law system, the conceptual legislative basis where the law represents the axiomatic system of the norms that

\footnotetext{
${ }^{98}$ In the event a commercial custom or dispositive norm is included in the terms of the contract, it is regarded as a condition of this.

${ }^{99}$ There is an exception to the general rule prioritizing a dispositive norm in relation to commercial custom. It is contained in the rules of the Civil Code concerning the performance of obligations (Art. 311 and 312) there is an exception to the general rule prioritizing a dispositive norm in relation to commercial custom: commercial custom takes priority in those rules. The Russian contract law rules contain also the exclusion to the general rules on the hierarchy of contract conditions concerning imperative norms. In accordance with the Article 422.2 of the Civil Code, the terms of contract could take priority over the imperative norms, if these are enacted after the conclusion of the contract. And it is only the law (not any other normative act) which may include a provision which supersedes the term of contract.
} 
- Exists without gaps or gives answers to all questions;

- Is unambiguous or does not contain a proposition and its negation at the same time; and

- Gives the only right answer or does not contain alternatives to the provided prescriptions, prohibitions and powers.

Russian law is extensively codified, and written law, in which form not only proper legal rules but also abstract general concepts and general principles are shaped, holds a very strong position. Thus, concepts and general rules dominate at the expense of concrete rules in Russian law. Thus, Russian business law operates basically by legislatively fixed terms and concepts, wherefor prescriptiveness and strict dogmatism are its characteristics.

Specific for the Russian legal discourse is also that law is associated traditionally in Russian culture with pravda (often meaning positive law codification) that is also identified with right and justice implying equity and even truth (veritas). The absence of strict differentiation of these concepts, adopted in the Russian Orthodoxy, is still characteristic for Russian legal culture in general.

Characteristic for Russian legal discourse are also the following features:

- Scientist believe in the power of the constantly modernising law, where

- Legal science is regarded as the system of constantly growing and accumulating knowledge ${ }^{100}$.

Specific to Russian law is also

- Reduction of law to statutes and

- Identifying law with the state as well as

- Ignorance of soft law and alternative means for settling disputes, and that

- The idea of 'the only one proper solution' still dominates the Russian legal thought.

Classical legal thinking is still dominating in Russian law, where the law is held to be a closed system and judicial decisions are deductively (syllogistically) constructed. And it means, general rules are applied to the concrete case following the idea of only one proper solution.

Characteristic for Russian law is still also a strong belief in the omnipotence of the legisprudential, law-based solutions, which is reflected in the dominance of statute law. Together with the overemphasised role of the state, the legalpositivistic approach, where statute law (in the form of written legal source) is identified with law, has been dominant in Russian law during its modern and contemporary history. The question is if Russian law ought to be based on

\footnotetext{
${ }^{100}$ Seeking for verity and discovery of the universal laws of the society and law is still a significant challenge for the Russian legal science. Top of the Russian legal science is occupied by the verity holders, and many legal scholars are eager to participate into the scientific construction of the future, at now for instance, dealing with the problems of artificial intelligence and digitalisation is actual.
} 
practical reasonability, instead of conceptual consistency, obviously oriented to the algorithmizing of the legal regulation of entrepreneurial activity. ${ }^{101}$

\section{Conclusion}

Russian law has not traditionally properly recognised trade customs as a legal source ignoring the fact that the origin of the western business law is in the commercial law, or, the law merchant, that had grown out of the customs and usages of merchants, existed before the emergence of law itself, and this law has reserved its self-regulatory and dispositive nature even in the process of formalizing the law into the legislation, characteristic for the continental law, that introduced public regulation in respect of commercial activities. Due to it, the Russian legal discourse is quite different to what is generally represented as the Western legal discourse.

Furthermore, although Russian business law has been developed under the influence of Western law, the idea of the legislatively established legal surveillance of business activities, where written law is regarded as a progressive means of regulation, plays still an important role, and for instance, the breach of the law requirements is a sine qua non condition for civil liability (for damages) in Russia.

The history of Russia could be regarded as partly the history of its ideocracy. It started with the guarding of orthodox Christianity, continued with pretences of being a "Third Rome" and ended with promises of the scientifically proven communist future. At present, Russia enjoys with the patriotism, but otherwise is further strengthening its pluralistic governance.

Obviously, Russian legal system will continue its development based on its legislative basis, however, with growing significance of the decisions of the Constitutional Court and Supreme Court. As to the fate of the legal doctrine, it ought to continue serving teaching and explanatory work and participating in the legislative work. It is obvious that Russian legal science is to abandon the Byzantine ideocratic tradition in order to concentrate on the instrumental functioning of the law, that is to serve the basic needs of the social and in particular economic development and means active role of the state in facing great challenges. It does not mean that the cultural and moral values inherited from Byzantine that still identifies the Russian culture are to be thrown away.

And finally, regardless the doctrinal inadequacy, Russian law manages to correspond to the needs of business activities owing to the active role of the judicial bodies in securing the adequacy of the Russian legal system. However, in respect of business activities, it also needs favouring the application of customs as well as soft law and alternative means for settling legal collisions.

\footnotetext{
${ }^{101}$ For more on the essentials of Russian law, see Orlov (2011): 1-5 and Orlov (2015) at 1 and the material cited therein.
} 


\section{References}

Antonov, M. (2020). 'The Varieties of Symphonia and the State-Church Relations in Russia' in Oxford Journal of Law and Religion 9(3):552-570.

Avenarius, M. (2014). Fremde Traditionen des römischen Rechts. Einfluß, Wahrnehmung und Argument des »rimskoe pravo" im russischen Zarenreich des 19. Jahrhunderts. Göttingen: Wallstein.

Bohanov A. (2002). Самодержсавие: Идея ирарской власти [Аиtocracy Idea of czar's power. Moscow.

Bohanov, А. (2004). 'Самодержавие - русская форма монархического авторитаризма [Autocracy-Russian form of monarchist autoritarianism]' in Московский журнал [Moscow Journal] 3:38-42.

Butler, W.E. (2009). Russian Law. Oxford University Press.

van Caenegem, R.C. (1992). An historical introduction to private law. Cambridge University Press.

Chestnov, I.L. (2004). Методология и методика юридического исследования [Methodology and Methodics of Legal Research]. St Petersburg.

Chulev, B. (2015). 'Glagolitic. Glagoling (speaking) the Glagolic, its origins, chronology, preserved written monuments, etc.' https://www.academia.edu/17371522

Dorskaya, A.А. (2016). 'Эволюция российской модели государственности в ракурсе государственно-церковных отношений: традиционная и инновационная составляющие [Evolution of the Russian Model of Statehood in a Foreshortening of State and Church Relations: Traditional and Innovative Components]'. Экономика, педагогика и право [Economics, pedagogy and law]. 2:1.

Egidi, R. (2009). 'Von Wright's Philosophical Humanism' in European Journal of Pragmatism and American Philosophy [Online], I-1/2 | 2009. http://journals.Openedition.org/ejpa p/973. https://doi.org/10.4000/ejpap.973

Fogelson, Y. (2015). 'Возможность верховенства права в современной России [Possibility of rule of law in modern Russia]' in Хозяйство и право [Economics and Law] 12:28-52.

Giaro, T. (2015). 'Russia and Roman Law' in Rechtsgeschichte - Legal History 23:309319.

Hartmann, W. \& Pennington, K. (eds) (2012). The History of Byzantine and Eastern Canon Law to 1500. Catholic University of America Press.

Heuman, S.E. (1991).'Взгляд на правовую культуру предреволюционной России [Look at legal culture of pre-revolutionary Russia]'. Советское государство и право [Soviet State and Law]. 1:121-127.

Horujy, S.S. (2011). 'Russian Spiritual Tradition: Union of Conciliarity and Ascesis' in Horujy, S.S. Orthodox Spiritual Tradition and Russian World. Brotherhood of SS Peter \& Paul, Hong Kong: 7-24.

Ivanov, S.A. (2003). Византийское миссионерство [Byzantine missionary]. Moscow.

Kaufhold, H. (2012). 'Sources of Canon Law in the Eastern Churches' in Hartmann, Pennington: 215-342.

Klyuchevsky, V.O. (2000). Православие в России [Orthodoxy in Russia]. Moscow.

Kourany, J.A. (1998). Scientific Knowledge: Basic Issues in the Philosophy of Science. Wadsworth.

Loskutov, V.G. \& U.G. Tribunskaya (2015). 'Концепция державности как инструмент анализа современного кризиса социально-экономической системы России [Great power statehood conception as a tool of analysis of modern crisis of socioeconomic system of Russia]'. Развитие политико-экономической мысли в современной Poccuu [Development of political and economic mind in modern Russia] in Tambov, 
pp. $345-354$.

Mamzin, А. (2008). История и философия науки [History and Philosophy of Science]. St Petersburg.

Mitrofanov, A.Y. (2011). 'Формирование византийского «кодекса канонов» [Forming the byzantine «codex of canons»]' in Государство, религия, иерковь в России и за рубежсом [State, religion, church in Russia and abroad]: 92-99.

Munchaev, V.M. \& Ustinov, Sh.M. (2009). История Pоссии [History of Russia]. Moscow.

Muravyev A. (2003) 'Церковное право [Church law]' Отечественные записки. [Patriotic Notes] 2: 318-325.

Orlov, V. (1999). Entrepreneurship in Russia. Finnish Lawyers' Publishing. Helsinki.

Orlov, V. (2011). Introduction to Business Law in Russia. Ashgate.

Orlov, V. (2015). Alternatives to capital-oriented corporations under Russian law. Research Handbook on Partnerships, LLCs and Alternative Forms of Business Organizations. Edward Elgar Publishing.

Orlov, V. (2019). 'Legal Sources and Interpretation in Russian Civil Law' in New Challenges of the Law in a Permeable World. Athens Institute for Education and Research, at 147-165.

Ostroukh, A. (2013). 'Russian Society and its Civil Codes: A Long Way to Civilian Civil Law' in Journal of Civil Law Studies 6(1):373-400.

Pihlajamäki, H. (2020). 'Länsimaisen oikeuden lähteet: varhaismodernista moderniin oikeuteen' in Lakimies 7-8:1126-1145.

Pokrovsky, J. (1998). История римского права [History of Roman law]. St Petersburg.

Poldnikov, D. (2019). 'Byzantine Roman law studies in Russia within the framework of political ideologies,' in: 'Ius commune graeco-romanum': essays in honour of Prof. Dr. Laurent Waelkens. Leuven: Peeters Publishers, pp. 147-164.

Puginsky, B.I. (2013). Коммерческое право России [Commercial law of Russia]. Moscow.

Rudokvas, A.D. (1998). 'Иосиф Алексеевич Покровский и изучение римского права в России [Yosiph Alekseevich Pokrovsky and studies of Roman law in Russia]' in Pokrovsky (1998) pp. 5-11.

Smith, G.B. (1996). Reforming the Russian Legal System by Gordon B. Cambridge University Press.

Tsypin, V.A. (1994). Церковное право [Church law]. Moscow.

von Wright, G. H. (1971). Explanation and understanding. Routledge \& Kegan Paul, London.

Zenkovsky, V.V. (1989). История русской философии [History of Russian Philosophy]. Paris. 